\title{
Characterization of biomasses from the north and northeast regions of Brazil for processes in biorefineries
}

\author{
Magale Karine Diel RAMBO ${ }^{1 \star}$, Gerso Pereira ALEXANDRE ${ }^{1}$, Michele Cristiane Diel RAMBO², \\ Aparecido Roberto ALVES 3 , Wokimar T. GARCIA ${ }^{3}$, Edmond BARUQUE ${ }^{4}$
}

\begin{abstract}
In search for renewable energy sources, the Brazilian residual biomasses stand out due to their favorable physical and chemical properties, low cost, and their being less pollutant. Therefore, they are likely to be used in biorefineries in the production of chemical inputs to substitute fossil fuels. This substitution is possible due to the high contents of carbohydrates $(>40 \%)$, low contents of extractives $(<20 \%)$, ashes $(<8 \%)$ and moisture $(<8 \%)$ found in these residual biomasses. High calorific values of all residues also offer them the chance to be used in combustion. A principal components analysis (PCA) was performed for better understanding of the samples and their hysic-chemical properties. Thus, this study aimed to characterize biomasses from the north (babassu residues, such as mesocarp and endocarp; pequi and Brazil nut) and northeast (agave and coconut) regions of Brazil, in order to contribute to the preservation of the environment and strengthen the economy of the region.
\end{abstract}

Keywords: bioproducts; biorefinery; hysic-chemical properties; lignocellulosic residues.

Practical Application: The Production of Sustainable Biofuels from the Residues and Wastes of Brazil principally of north of the country with technologies to help reduce the need for fossil diesel imports, improving the security of energy supply. Therefore rapid analytical methods can be used to analysis biomass and waste feedstocks pointing out the more promising candidates.

\section{Introduction}

In Brazil, over 90\% of the energy is produced in hydroelectric power plants, which depend on water in adequate levels to generate energy. Unfortunately, in 2014/2015, low rainfall affected energy production, leading to the current energy crisis. Given this environmental crisis, lignocellulosic materials have become a potential alternative as energy source and inputs to human activities (Dhillon \& Wuehlisch, 2013; Rodrigues, 2011). Furthermore, residues from the biomass must have proper destination, in order to prevent environmental damage due to the unbalance caused by inappropriate disposal.

The use of such residues and materials requires creative solutions that take economic and environmental aspects into account. For this, it is essential to know the biomass composition, in order to make use of these renewable sources, with the possibility to generate an array of bioproducts of appreciable value-added (Goldemberg, 2006).

Several lignocellulosic residues may be used to produce energy and as chemical inputs. Many of these biomasses, such as coconut husk, Brazil nut epicarp and mesocarp, babassu endocarp and mesocarp, pequi stone, agave, among others, present high levels of carbohydrates and lignin, which can be converted into high value-added products (Bevilaqua et al., 2013; Bridgwater, 2012; Gupta \& Verma, 2015; Rambo et al., 2011, 2013, 2015).

Besides the favorable chemical composition, another factor of use of these materials is the amount of wastes produced in these regions. According data of 2010 from the Brazilian Institute of Geography and Statistics (Instituto Brasileiro de Geografia e Estatística, 2015) were produced 40,000 tons of Brazil nuts; 5,786 tons of pequi and about 106,055 tons of babassu. For the coconut, approximately 6.7 million tons of shells are produced per year (Silva \& Jerônimo, 2012). According Souza (2009) agave covers an extensive area of some 230,000 hectares of planted land.

In this context, the use of such waste materials has stimulated the determination of their physical and chemical properties, mainly of their major constituents (cellulose, hemicellulose and lignin), which have been increasingly employed in biorefining processes. The term biorefinery refers to the conversion of biomass into chemical inputs, energy and fuels, with minimum waste, low emission of pollutants and maximization of the use of renewable biomass to replace petroleum-based products. The focus of the present work is the integrated biorefinery, a conceptual facility at which different processes of biomass conversion take place 
in a way that the product of a process becomes the feedstock of the following process (Charlton et al., 2009).

In a tropical country of continental dimensions like Brazil, biomass is the natural substitute to petroleum. Given this possibility, Brazil has been seeking new alternatives to diversify its current energy matrix. Among the alternatives, the use of forest and agricultural residues stands out, since their processing is of great environmental and socioeconomic interest. In addition, such residues do not affect food production, neither do they cause devastation or other kinds of aggression to forests (Shuchardt et al., 2001), not to mention they are abundant residues in the country.

Besides the sugar cane bagasse and straw, which have already been well established, other renewable materials, obtained from agro-industrial and agroforestry residues, must be considered (Bonelli et al., 2001; Cinelli et al., 2014; Rambo et al., 2015; Teixeira, 2008) to avoid dependence on a sole source and a sole region of the country (Sasmal et al., 2012). This way, the present work seeks to encourage the use of lignocellulosic residues found in the north and northeast regions of Brazil, through physical and chemical characterizations, thus contributing to the diversification and decentralization of the energy supply and to energetic self-sufficiency at the local, regional and national levels.

\section{Materials and methods}

\subsection{Samples}

Five typical biomasses from the north and northeast regions of Brazil were properly collected between February/2014 and August/2014. These samples were kept frozen in plastic bags awaiting the next steps of the process. After dried at room temperature, they were ground in a cutting mill (MA 580, Marconi) and sieved in an automatic sieve shaker (VP-01, Bertel), until particles of $355 \mu \mathrm{m}$ in diameter (45-mesh sieve). Subsequently, they were stored in hermetically sealed vials and then classified. The evaluated feedstocks were the following: Cocos nucifera (coconut, used in husks), Orbygnia phalerata (babassu, whose endocarp and mesocarp were used), Berthollitia excelsa H.B.K. (Brazilian nut, whose endocarp and mesocarp were used), Agave salmiana (agave) and Caryocar brasiliense Camb (pequi, whose seed was used).

\subsection{Proximate analysis}

The moisture content was determined after the sample ( $1 \mathrm{~g})$ was heated to $105 \pm 5^{\circ} \mathrm{C}$ in an oven ( $315 \mathrm{Se}$, Fanem) for 8 hours. After that, it was placed in a desiccator for $20 \mathrm{~min}$ to be cooled. The ash content (AC) was determined according to the ASTM D3174-04 (American Society for Testing and Materials, 2004). The volatile matter content (VMC) was determined according to the ASTM D3175-07 (American Society for Testing and Materials, 2007). Fixed carbon (FC) content is an indirect measure and was calculated through Equation 1:

$\mathrm{FC}(\%)=100-(A C+V M C)$

\subsection{Elemental analysis}

The elemental analyses of carbon, hydrogen and nitrogen $(\mathrm{CHN})$ were performed in a Perkin Elmer elemental analyser model PE-2400. The percentage of oxygen (O) was determined by difference. All values are calculated on a moisture-free and ash-free basis.

\subsection{Gross calorific value (GCV)}

The gross calorific value (GCV) was determined in a static jacket bomb calorimeter (IKA C2000), according to the ASTM D 5865-04 methodology (American Society for Testing and Materials, 2013).

\subsection{Soxhlet extraction}

This procedure was performed in a Soxhlet extractor, where the extraction cartridges received $3 \mathrm{~g}$ of each sample of biomass. After that, they were covered with cotton wool and then taken to the extractor, with $190 \mathrm{~mL}$ of ethanol (70\%), for 7 hours in reflux (National Renewable Energy Laboratory, 2011a).

After the end of the reflux, the cartridges were taken and placed on petri dishes on the counter for 48 hours to be dried. After 48 hours, the moisture content of the extracted sample was determined again, so that the extractives content was calculated according to the weight loss after the extraction, deducting the moisture.

\subsection{Acid hydrolysis}

The acid hydrolysis step was performed according to the methodology of the National Renewable Energy Laboratory (National Renewable Energy Laboratory, 2011b) for determination of structural carbohydrates and lignin in biomass. Pressure tubes were used, in which $0.3 \mathrm{~g}$ of the extracted biomass were placed, and $3.0 \mathrm{~mL}(4.91 \mathrm{~g})$ of $\mathrm{H}_{2} \mathrm{SO}_{4}$ at $72 \%(\mathrm{~m} / \mathrm{m})$; then, the tubes were taken to a water bath (TE 056, Tecnal) for $120 \mathrm{~min}$ at $30{ }^{\circ} \mathrm{C}$ and shaken every $10 \mathrm{~min}$. This is the primary hydrolysis step. Subsequently, $84 \mathrm{~mL}$ of deionized water were added so that the concentration of sulfuric acid was reduced to $4 \%(\mathrm{~m} / \mathrm{m})$; the tubes were then taken to an autoclave (AV 18, Phoenix) for 1 hour at $120^{\circ} \mathrm{C}$ (secondary hydrolysis step).

After this step, the hydrolyzed solution was filtered in crucibles of medium porosity (10 to $15 \mu \mathrm{m}$ ) using a vacuum pump (NOF-650). The solids retained in the filter crucibles were taken to an oven at $105^{\circ} \mathrm{C}$ so that the content of acid-insoluble residue (AIR) was determined, and then kept in a muffle furnace for 4 hours at $575^{\circ} \mathrm{C}$, in order to obtain the acid-insoluble ash (AIA). From the difference between AIR and AIA, the content of insoluble lignin - also known as Klason Lignin (KL) - was determined. The filtrate (hydrolysate) was stored in a freezer for future analyses. This solution contains the acid-soluble lignin (ASL) and any other soluble acid components of the biomass, such as the hydrolyzed sugars. 
The moisture-free content of cellulose and hemicellulose (holocellulose) of the biomasses was estimated by the difference between the other parameters (extractives, total lignin and ashes).

\subsection{UV spectroscopy}

Typically, the ASL is determined using spectrophotometric methods of absorption of the ultraviolet region. The hydrolysate was placed in a quartz cuvette and diluted when necessary, and the UV spectra were collected in a UV-Vis spectrophotometer (DR 5000, HACH). The blank test for these analyses consisted of a solution of $\mathrm{H}_{2} \mathrm{SO}_{4}$ at $4 \%(\mathrm{~m} / \mathrm{m})$ and the wavelength was $205 \mathrm{~nm}$ at molar absorptivity of $113 \mathrm{M}^{-1} \mathrm{~cm}^{-1}$ (Sluiter et al., 2010).

\subsection{Vis-NIR spectroscopy}

The spectra in the visible and the near-infrared regions were collected using a FOSS single beam spectrophotometer (XDS FOSS, Hillerød), in the diffuse reflectance mode, over a spectral range of 400 to $2500 \mathrm{~nm}$. Each sample was analyzed in duplicate, and the average spectrum was used.

\subsection{X-ray diffraction}

The X-ray diffraction was performed using a Shimadzu diffractometer model XRD-700. The scanning was performed over the angle range of $5^{\circ}<2 \Theta>50^{\circ}$, and the source of radiation used was $\mathrm{Cu} \mathrm{Ka}$. The crystallinity index (CI) was calculated from the ratio of the height of the crystalline peak (Ic) and the height of the amorphous peak (Segal et al., 1959).

\section{Results and discussion}

It is essential to know and to understand the physical and chemical properties of the residual lignocellulosic biomasses, because a more comprehensive biomass optimization in a biorefinery process depends on this characterization. Thus, we will present and discuss some of the properties that were analyzed in the potential biomasses.

\subsection{Proximate analyses}

The proximate analysis consists of the collection of the following parameters: moisture, ashes, VMC and FC with the values observed in Table 1.

From these data, it was possible to conclude that:

1. Babassu mesocarp - with high ash content (normal for this kind of biomass) and rich in volatiles (79\%) - is useful as fuel in furnaces, but with low potential of carbonization (due to the high content of volatiles);

2. Babassu endocarp - with high ash content (still normal for this kind of biomass) and higher content of FC - is suitable for both burning and carbonization, and reinforces the tradition of using it to produce charcoal;
3. Pequi - with average ash content (within the expected 5\% for biomasses), providing very rapid burning and leading to a low carbonization yield;

4. Brazil nut mesocarp - low ash percentage (less than $1 \%$ ), but high in FC. This biomass provides high yields in charcoal production;

5. Agave - with average ash content (within the expected $5 \%$ ) and poor in fixed carbon, which makes it difficult to obtain charcoals with better chemical properties;

6. Coconut husks and Brazil nut epicarp- present similarly high contents of VMC and FC; the ash content is within the expected. Thus, both are useful for charcoal production.

The calculation of the VMC and FC contents are important, because from it, the potential of these materials to the production of energy through combustion (Vieira et al., 2013), or to the production of charcoal, respectively, may be inferred.

The moisture content is a crucial efficiency parameter, because it directly affects the combustion processes, negatively influencing the calorific value; it also interferes with transportation costs, drying, storage and handling of the biomass (Behera et al., 2014; Charlton et al., 2009; Everard et al., 2012). Likewise, the inherently high concentration of ashes in some biomasses might be a challenge in the furnaces, since there is higher probability of ash deposition and slags like incrustations, as well as corrosion of the surfaces of the furnace (Agbor et al., 2014), not to mention that the ashes might lead to problems in the processes of acid and/or enzymatic hydrolysis. Although some specialists specify an ash concentration of approximately $5 \%$, the concentration of ashes from different kinds of biomass varies significantly, from 0.44 (pine wood) to 7.63 (rice husks) (Rambo et al., 2011).

\subsection{Elemental analysis}

Through the elemental analysis it was possible to determine the percentage of $\mathrm{C}, \mathrm{H}, \mathrm{N}$ and $\mathrm{O}$ in the biomasses (Table 2). The atomic $\mathrm{O} / \mathrm{H}$ and $\mathrm{H} / \mathrm{C}$ ratios were also calculated in order to indirectly check the aromaticity of the samples, estimate the abundance of oxygen within the functional groups and estimate the calorific value (Cunha et al., 2007).

Table 1. Proximate analyses (\%) of lignocellulosic biomass residues.

\begin{tabular}{|c|c|c|c|c|}
\hline $\begin{array}{c}\text { Biomass/ } \\
\text { Parameters }\end{array}$ & Moisture & Ash & VMC & $\mathrm{FC}$ \\
\hline Agave & $4.07 \pm 0.24$ & $5.80 \pm 0.15$ & $77.16 \pm 0.95$ & $16.95 \pm 0.56$ \\
\hline $\begin{array}{l}\text { Coconut } \\
\text { shells }\end{array}$ & $8.11 \pm 0.08$ & $3.63 \pm 0.20$ & $75.97 \pm 0.43$ & $20.39 \pm 0.16$ \\
\hline $\begin{array}{l}\text { Babassu } \\
\text { endoc. }\end{array}$ & $8.32 \pm 0.07$ & $8.22 \pm 0.47$ & $59.41 \pm 0.57$ & $32.36 \pm 0.07$ \\
\hline $\begin{array}{l}\text { Brazil nut } \\
\text { epic. }\end{array}$ & $11.97 \pm 0.39$ & $3.58 \pm 0.65$ & $71.20 \pm 0.25$ & $25.21 \pm 0.28$ \\
\hline $\begin{array}{l}\text { Babassu } \\
\text { mesoc. }\end{array}$ & $8.30 \pm 0.51$ & $6.06 \pm 0.00$ & $79.12 \pm 0.45$ & $14.80 \pm 0.31$ \\
\hline $\begin{array}{l}\text { Brazil nut } \\
\text { mesoc. }\end{array}$ & $7.67 \pm 0.06$ & $0.86 \pm 0.00$ & $60.24 \pm 0.67$ & $38.89 \pm 0.47$ \\
\hline Pequi & $7.20 \pm 0.23$ & $2.86 \pm 0.25$ & $70.33 \pm 0.89$ & $26.80 \pm 0.45$ \\
\hline
\end{tabular}


Table 2. Elemental analysis (\%) and atomic rations of lignocellulosic biomass.

\begin{tabular}{|c|c|c|c|c|c|c|c|}
\hline $\begin{array}{l}\text { Biomass/ } \\
\text { Parameter }\end{array}$ & $\mathrm{C}$ & $\mathrm{H}$ & $\mathrm{N}$ & $\mathrm{O}$ & $\mathrm{O} / \mathrm{C}$ & $\mathrm{H} / \mathrm{C}$ & $\mathrm{C} / \mathrm{N}$ \\
\hline Agave & $47.15 \pm 0.41$ & $5.63 \pm 0.20$ & $0.26 \pm 0.04$ & $41.10 \pm 0.35$ & $0.70 \pm 0.38$ & $1.43 \pm 0.30$ & $211.57 \pm 0.22$ \\
\hline Coconut shell & $49.03 \pm 0.17$ & $5.85 \pm 0.11$ & $0.30 \pm 0.05$ & $41.20 \pm 0.43$ & $0.60 \pm 0.30$ & $1.43 \pm 0.14$ & $190.67 \pm 0.11$ \\
\hline Brazil nut epic. & $46.29 \pm 0.50$ & $5.37 \pm 0.12$ & $0.74 \pm 0.17$ & $44.00 \pm 0.32$ & $0.70 \pm 0.41$ & $1.39 \pm 0.31$ & $72.98 \pm 0.33$ \\
\hline Babassu mesoc. & $47.13 \pm 0.31$ & $5.17 \pm 0.18$ & $0.97 \pm 0.22$ & $40.70 \pm 0.15$ & $0.60 \pm 0.23$ & $1.32 \pm 0.25$ & $56.69 \pm 0.26$ \\
\hline
\end{tabular}

The $\mathrm{H} / \mathrm{C}$ ratio is considered to be the aromaticity index and is associated with higher calorific value biomasses. Samples with lower $\mathrm{H} / \mathrm{C}$ ratio, are the samples with the higher resistance to thermodegradation (Stevenson, 1994). The O/C ratio, in turn, allows the estimation of the oxygen abundance within functional groups (Bravard \& Righi, 1991).

Biomasses that are rich in nitrogen $(\mathrm{N})$, such as the residues from the babassu industry (Table 2), may be used as fertilizers in the soil, because it is an essential nutrient to plants, whereas a low atomic $\mathrm{C} / \mathrm{N}$ ratio contributes to microbial degradation (Cunha et al., 2007). When compared to some fossil fuels, most of the biomass fuels contain less carbon and nitrogen, and more hydrogen and oxygen, causing the biomass to be much less energy-dense than the fossil derivatives (Agbor et al., 2014).

The results from Table 1 and 2 were analyzed according to analysis of variance designs by F- test and indicate that there is no evidence of significant difference between the averages of the samples, at the level of 5\% significance.

\subsection{Majority lignocellulosic composition}

Holocellulose has been widely used in the production of bioproducts due to the fact that it is relatively easy to be hydrolyzed into its monosaccharides, releasing inputs of great value; they may also be fermented to provide other important chemicals, such as ethanol in the case of hexoses (Hayes, 2009). Biomasses must have at least $25 \%$ of carbohydrates in order to become potential inputs to the supply of bioproducts. All the biomasses in the north and northeast region presented percentages over $30 \%$ (Figure 1). But the most promising feedstocks are the Brazil nut mesocarp with $65.98 \%$, follow by babassu residues, mesocarp and endocarp, respectively with $63.8 \%$ and $57.6 \%$ of holocellulose content.

Lignin is a byproduct of the hydrolysis process that may be used as thermal energy source, and in the pyrolysis processes, to provide bio-oil and residual charcoal, which are potential sources of valuable inputs for the chemical industry and agriculture (Bridgwater, 2012; Rambo et al., 2014). The biomasses of Brazil nut epicarp and coconut shell shows high percentages of total lignin, respectively of $59.4 \%$ and $40.8 \%$, that indicates a good use for pyrolysis and others thermal process.

Low percentage of extractives is essential when it comes to reducing production costs, both economically and environmentally,

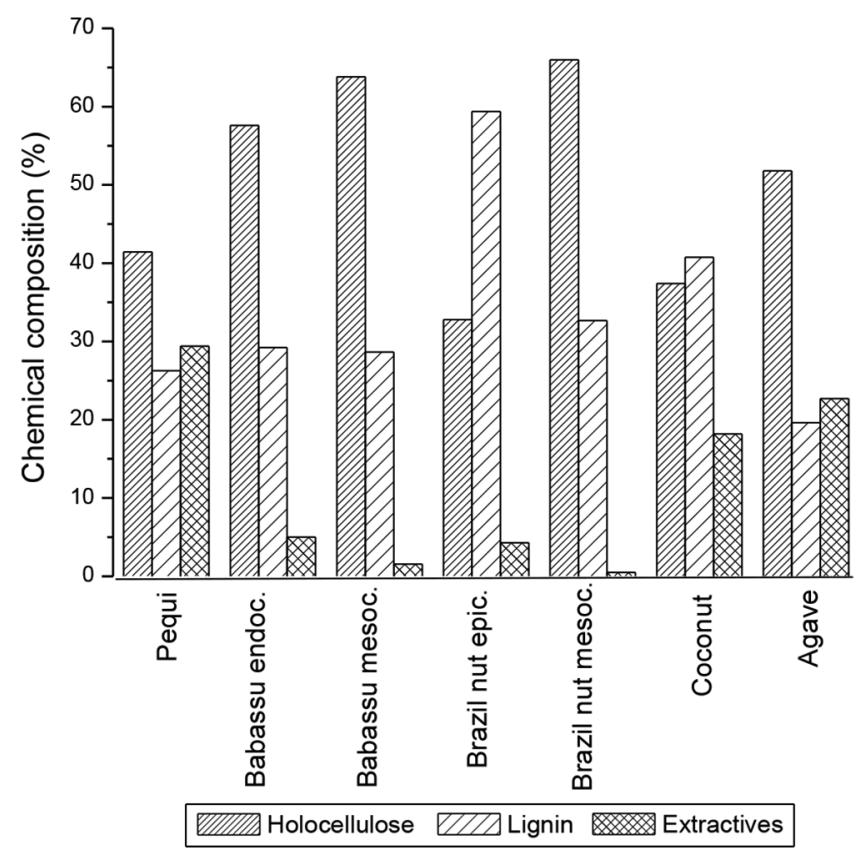

Figure 1. Majority chemical composition of biomasses.

because the higher the content of extractives, the higher the consumption of solvents and the generation of residues; they may interfere with the acid hydrolysis and their content must be reduced (Naik et al., 2010). All the samples showed a low extractives content $(<20.0 \%)$ except pequi and agave biomasses.

\subsection{Calorific value}

Calorific value (CV) is defined as the amount of energy contained in a fuel. Babassu residues - mesocarp and endocarp - showed, respectively, 19.07 and $19.03 \mathrm{MJ} / \mathrm{kg}$, and were the biomasses that presented the highest potential in terms of direct combustion as energy source to replace fossil fuels, followed by coconut husks (18.71 MJ/kg). Brazil nut epicarp, pequi and agave, showed CV between 17.2 and $17.8 \mathrm{MJ} / \mathrm{kg}$, whereas the Brazil nut mesocarp showed a much lower CV $(12.5 \mathrm{MJ} / \mathrm{kg})$ when compared to the other samples.

Erol et al. (2010), evaluated the CV of biomasses using the results of the proximate analysis, which makes it cheap and 
simple to determine, since the proximate analysis has a much lower cost in comparison to the analysis of combustion of $\mathrm{CV}$.

In this study, a Pearson correlation (R) was performed with the results of proximate, elemental and majoritary analyses, in order to assess which parameters influence the CV negatively and positively.

Fuels consist mostly of hydrogen and carbon; their calorific values are, respectively, 10.8 and $34.08 \mathrm{MJ} / \mathrm{kg}$. This way, the higher amount of hydrogen in fuel, the higher its calorific value (Everard et al., 2012). However, for the biomasses studied, the exact opposite was observed. The contents of $\mathrm{H}$ and $\mathrm{C}$ are negatively related to the CV. McKendry et al. (2002) found that samples with lower $\mathrm{O} / \mathrm{C}$ and higher $\mathrm{H} / \mathrm{C}$ ratios, are the biomass with higher calorific values, which did not occur in this study either.

High contents of ashes and moisture may affect negatively the combustion of the biomass (Everard et al., 2012), affecting the $\mathrm{CV}$, which was observed in this study only for moisture content. The correlation between ashes and CV was insignificant $(\mathrm{R}<0.30)$. High contents of extractives may also influence negatively the calorific value (Wild et al., 2011). On the other hand, the calorific value is proportional to the content of extractives, because these have less oxygen than the polysaccharides present in hollocelulose.

According to Pearson correlation, neither of the parameters had a significant positive influence on the $\mathrm{CV}$. The correlations between the calorific value and the results of moisture content provided regression coefficients $(\mathrm{R})$ above 0.70 , with a correlation that might be considered significant. Therefore, the data from the proximate and elemental analyses are not acceptable to make reliable estimates of $\mathrm{CV}$ in a lignocellulosic biomass.

\subsection{Spectroscopy of the Vis-NIR region}

The raw spectra of the region that ranges from Vis $(400-900 \mathrm{~nm})$ to NIR (900-2500 nm) of each biomass were collected (Figure 2). The main bands in the visible region are located at approximately $460 \mathrm{~nm}$ and $680 \mathrm{~nm}$, both associated with chlorophyll (types B

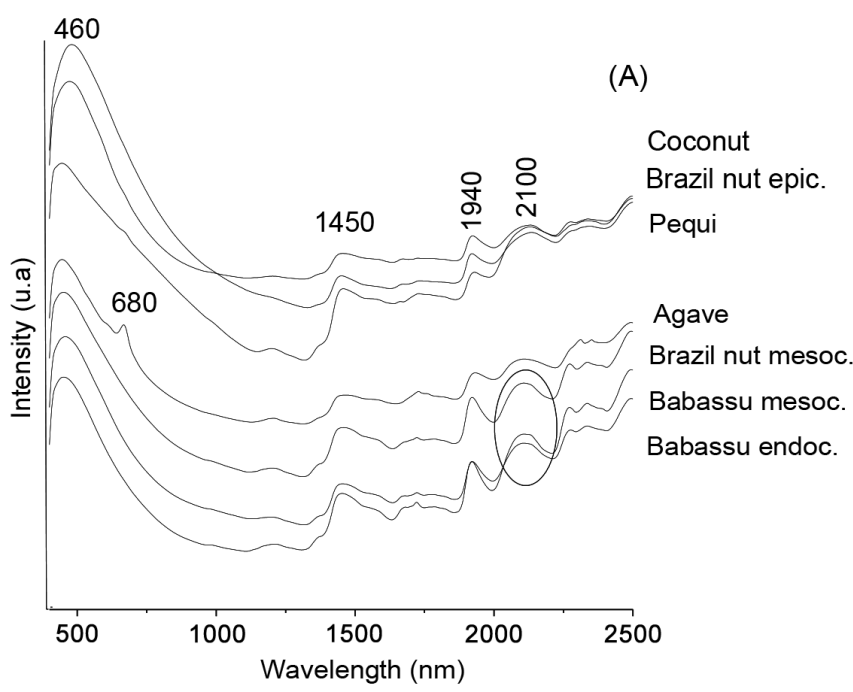

Figure 2. Visible and Near-infrared spectral analysis of the raw biomasses. and $\mathrm{A}$, respectively, that are present in green plants). This way, the band centered in the region of $680 \mathrm{~nm}$ is more prominent in green biomasses, such as agave leaves, which are rich in these photosynthetic pigments. Stretching bands of O-H and combination bands in the NIR region, at 1450 and $1940 \mathrm{~nm}$, respectively, were associated with water signals. Still in the NIR region, a typical band of carbohydrates was found at $2100 \mathrm{~nm}$ (Shenk et al., 2008). According to the Figure 1, the biomasses with higher contents of holocellulose were the ones whose spectra presented more evident bands in this region (Brazil nut mesocarp and babassu residues).

\subsection{X-ray diffraction}

The data obtained show that the biomasses presented crystalline cellulose percentages that varied between 30.8 and $56.0 \%$; the latter was associated with Brazil nut mesocarp, and the first with pequi biomass. The average was $45.0 \%$ for the other biomasses, which is expected for these kinds of biomass. Brazil nut epicarp, for example, shown $36.6 \%$, follow by coconut (44.3\%), babassu endocarp (47.1\%), babassu mesocarp (47.6\%), and agave $(50.4 \%)$.

Although it has been reported that crystallinity negatively affects the process of acid hydrolysis, in this study we did not observe a relation between a higher level of crystallinity and lower hydrolysis yields, which is given by the content of carbohydrates; this indicates that the variation range of crystallinity did not affect the yield of hydrolyses.

X-ray diffraction measures were important to identify the crystallinity of the material, since it negatively influences the efficiency of the acid hydrolysis. Lesser crystallinity indexes contribute to the hydrolysis of lignocelluloses. The hydrophobicity of crystalline cellulose makes it more resistant to acid hydrolysis because it forms a dense water layer near the surface of the hydrated cellulose (Himmel et al., 2007).

\subsection{Principal components analysis}

The exploratory multivariate analysis of autoscaled analytical data with varimax rotation using the Principal Components Analysis (PCA) is shown in Figure 3. The first two PC explain 28 and $25.6 \%$ of the total variance, respectively. The PC2 (Figure 3a) was important to differentiate agave from the Brazil nut epicarp, with high contents of extractives/ASL and high contents of KL/moisture, respectively. The PC1 differentiated samples with higher contents of carbon and VMC (coconut and babassu mesocarp), from samples with high contents of $\mathrm{FC}$ and higher $\mathrm{H} / \mathrm{C}$ and $\mathrm{O} / \mathrm{C}$ atomic ratios (babassu endocarp and nut mesocarp).

A relation between the carbohydrates content and the crystallinity index was observed, and shown by PC4 (Figure 3b), which explains $16.3 \%$ of the variance. The biomasses with higher content of holocellulose showed higher percentages of crystalline cellulose (babassu and nut mesocarp). The main parameters responsible for the distinction of babassu samples with $24.4 \%$ of the variance explained (PC3 with negative score) from the others were $\mathrm{CV}$ and ash content, indicating that babassu biomasses, has the higher ash and CV content. 

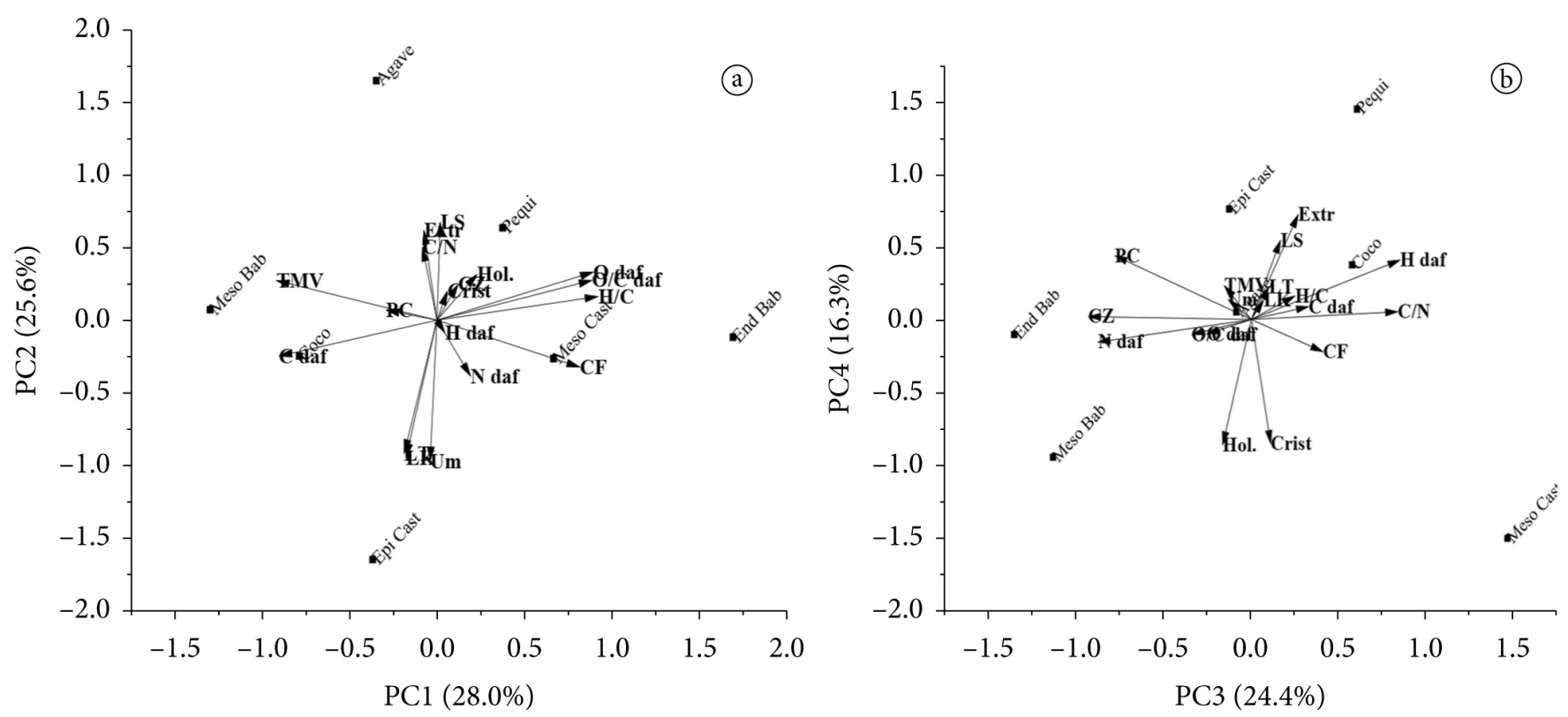

Figure 3. Principal component analysis (a) scores and (b) loadings.

In general, physico-chemical composition, mainly the parameters associated with carbohydrates content (crystallinity and holocellulose), lignin and CV were responsible for the distinction of the biomasses, thus confirming the efficient use of the PCA to sort out samples.

\section{Conclusion}

Thereby, it was found that the use of renewable resources is important to an economically viable and environmentally correct society. The residual biomasses analyzed in this work are abundant and promising in the north and northeast regions of Brazil, which makes them very attractive alternatives, and likely to become factors to profit and job creation. Physico-chemical characterizations showed that, in general, all residues are potential candidates and may provide an array of value-added products, because their parameters fit biorefinery requirements, such as: calorific value and high content of carbohydrates, low contents of moisture, extractives and ashes. Higher contents of lignin contribute to obtaining aromatic inputs and charcoal, including for agricultural use (biochar).

\section{Acknowledgements}

CNPq (420154/2013-2) for financial support and Embrapa Amapá for kindly providing the samples.

\section{References}

Agbor, E., Zhan, X., \& Kumar, A. (2014). A review of biomass co-firing in North America. Renewable \& Sustainable Energy Reviews, 40, 930-943. http://dx.doi.org/10.1016/j.rser.2014.07.195.

American Society for Testing and Materials - ASTM. ASTM D3174-04: standard method for ash in the analysis sample of coal and coke. West Conshohocken; 2004.
American Society for Testing and Materials - ASTM. ASTM D3175-07: standard method for volatile matter in the analysis sample of coal. West Conshohocken; 2007.

American Society for Testing and Materials - ASTM. ASTM D5865-04: standard test method for gross calorific value of coal and coke. West Conshohocken; 2013.

Behera, S., Arora, R., Nandhagopal, N., \& Kumar, S. (2014). Importance of chemical pretreatment for bioconversion of lignocellulosic biomass. Renewable \& Sustainable Energy Reviews, 36, 91-106. http://dx.doi. org/10.1016/j.rser.2014.04.047.

Bevilaqua, D. B., Rambo, M. K. D., Cardoso, A. L., Rizzetti, T. M., \& Martins, A. F. (2013). Cleaner production: levulinic acid from rice husks. Journal of Cleaner Production, 47, 96-101. http://dx.doi. org/10.1016/j.jclepro.2013.01.035.

Bonelli, P. R., Della Rocca, P. A., Cerrella, E. G., \& Cukierman, A. L. (2001). Effect of pyrolysis temperature on composition, surface properties and thermal degradation rates of Brazil Nut shells. Bioresource Technology, 76(1), 15-22. http://dx.doi.org/10.1016/ S0960-8524(00)00085-7. PMid:11315805.

Bravard, S., \& Righi, D. (1991). Characterization of fulvic and humic acids from an oxisol-spodosol toposequence of Amazonia, Brazil. Geoderma, 48(1-2), 151-162. http://dx.doi.org/10.1016/00167061(91)90013-J.

Bridgwater, A. V. (2012). Review of fast pyrolysis of biomass and product upgrading. Biomass and Bioenergy, 38, 68-94. http://dx.doi. org/10.1016/j.biombioe.2011.01.048.

Charlton, A., Elias, R., Fish, S., Fowler, P., \& Gallagher, J. A. (2009). The biorefining opportunities in Wales: Understanding the scope for building a sustainable, biorenewable economy using plant biomass. Chemical Engineering Research \& Design, 87(9), 1147-1161. http:// dx.doi.org/10.1016/j.cherd.2009.06.013.

Cinelli, B. A., Lopez, J. A., Castilho, L. R., Freire, D. M. G., \& Castro, A. M. (2014). Granular starch hydrolysis of babassu agroindustrial residue: A bioprocess within the context of biorefinery. Fuel, 124, 41-48. http://dx.doi.org/10.1016/j.fuel.2014.01.076. 
Cunha, T. J. F., Madari, B. E., Benites, V. M., Canellas, L. P., Novotny, E. H., Moutta, R. O., Trompowsky, P. M., \& Santos, G. A. (2007). Fracionamento químico da matéria orgânica e características de ácidos húmicos de solos com horizonte $\mathrm{A}$ antrópico da Amazônia (Terra Preta). Cunha Amazônica, 37, 91-98.

Dhillon, R. S., \& Wuehlisch, G. (2013). Mitigation of global warming through renewable biomass. Biomass and Bioenergy, 48, 75-89. http://dx.doi.org/10.1016/j.biombioe.2012.11.005.

Erol, M., Haykiri-Acma, H., \& Kücükbayrak, S. (2010). Calorific value estimation of biomass from their proximate analyses data. Renewable Energy, 35(1), 170-173. http://dx.doi.org/10.1016/j.renene.2009.05.008.

Everard, C. D., McDonnell, K. P., \& Fagan, C. C. (2012). Prediction of biomass gross calorific values using visible and near infrared spectroscopy. Biomass and Bioenergy, 45, 203-211. http://dx.doi. org/10.1016/j.biombioe.2012.06.007.

Goldemberg, J. (2006). The promise of clean energy. Energy Policy, 34(15), 2185-2190. http://dx.doi.org/10.1016/j.enpol.2005.03.009.

Gupta, A., \& Verma, J. P. (2015). Sustainable bio-ethanol production from agro-residues: a review. Renewable \& Sustainable Energy Reviews, 41, 550-567. http://dx.doi.org/10.1016/j.rser.2014.08.032.

Hayes, D. J. (2009). An examination of biorefining processes, catalysts and challenges. Catalysis Today, 145(1-2), 138-151. http://dx.doi. org/10.1016/j.cattod.2008.04.017.

Himmel, M. E., Ding, S. Y., Johnson, D. K., Adney, W. S., Nimlos, M. R., Brady, J. W., \& Foust, T. D. (2007). Biomass recalcitrance: engineering plants and enzymes for biofuels production. Science, 315(5813), 804-807. http://dx.doi.org/10.1126/science.1137016. PMid:17289988.

Instituto Brasileiro de Geografia e Estatística - IBGE. (2015, February 20). Aggregated Database. Retrieved from: www.ibge.com.br

McKendry, P., Ding, S. Y., Johnson, D. K., Adney, W. S., Nimlos, M. R., Brady, J. W., \& Mckendry, P. (2002). Energy production from biomass (Part 1): Overview of biomass. Bioresource Technology, 83(1), 37-46. http://dx.doi.org/10.1016/S0960-8524(01)00118-3. PMid:12058829.

Naik, S., Goud, V. V., Rout, P. K., Jacobson, K., \& Dala, A. K. (2010). Characterization of Canadian biomass for alternative renewable biofuel. Renewable Energy, 35(8), 1624-1631. http://dx.doi.org/10.1016/j. renene.2009.08.033.

National Renewable Energy Laboratory - NREL. (2011a). NREL/TP510-42618: determination of structural carbohydrates and lignin in biomass. Golden.

National Renewable Energy Laboratory - NREL. (2011b). NREL/TP510-42619: determination of extractives in biomass. Golden.

Rambo, M. K. D., Alves, A. R., Garcia, W. T., \& Ferreira, M. M. C. (2015). Multivariate analysis of coconut residues by near infrared spectroscopy. Talanta, 138, 263-272. http://dx.doi.org/10.1016/j. talanta.2015.03.014. PMid:25863400.

Rambo, M. K. D., Bevilaqua, D. B., Brenner, C. G. B., Martins, A. F., Mário, D. N., Alves, S. H., \& Mallmann, C. A. (2013). Xylitol from rice husks by acid hydrolysis and Candida yeast fermentation.
Quimica Nova, 36(5), 634-639. http://dx.doi.org/10.1590/S010040422013000500004.

Rambo, M. K. D., Cardoso, A. L., Bevilaqua, D. B., Rizzetti, T. M., Ramos, L. A., Korndörfer, G. H., \& Martins, A. F. (2011). Silica from rice husk ash as an additive for rice plant. Journal of Agronomy, 10(3), 99-104. http://dx.doi.org/10.3923/ja.2011.99.104.

Rambo, M. K. D., Novotny, E. H., Canellas, L. P., Aguiar, N. O., Auccaise, R., \& Rambo, M. C. D. (2014). Pyrolysis of banana and coffee residues after acid hydrolysis. Journal of Chemistry and Chemical Engineering, 8, 960-970.

Rodrigues, J. A. R. (2011). Do engenho à biorrefinaria. A usina de açúcar como empreendimento industrial para a geração de produtos bioquímicos e biocombustíveis. Quimica Nova, 34(7), 1242-1254. http://dx.doi.org/10.1590/S0100-40422011000700024.

Sasmal, S., Goud, V. V., \& Mohanty, K. (2012). Characterization of biomasses available in the region of North-East India for production of biofuels. Biomass and Bioenergy, 45, 212-220. http://dx.doi. org/10.1016/j.biombioe.2012.06.008.

Segal, L., Creely, J. J., Martin, A. E., \& Conrad, C. M. (1959). An empirical method for estimating the degree of crystallinity of native cellulose using the X-ray diffractometer. Textile Research Journal, 29(10), 786-794. http://dx.doi.org/10.1177/004051755902901003.

Shenk, J. S., Workman, J. J., \& Westerhaus, M. O. (2008). Application of NIR spectroscopy to agricultural products. In D. A. Burns \& E. W. Biurczak. Handbook of near-infrared analysis (3rd ed.). Florida.

Shuchardt, U., Ribeiro, M. L., \& Gonçalves, A. R. (2001). A indústria petroquímica no próximo século: como substituir o petróleo como matéria-prima? Quimica Nova, 24(2), 247-251. http://dx.doi. org/10.1590/S0100-40422001000200016.

Silva, G. O., \& Jerônimo, C. E. (2012). Estudo de alternativas para o aproveitamento de resíduos sólidos da industrialização do coco. Monografias Ambientais, 10, 2193-2208.

Sluiter, J. B., Ruiz, R. O., Scarlata, C. J., Sluiter, A. D., \& Templeton, D. W. (2010). Compositional analysis of lignocellulosic feedstocks. 1. Review and description of methods. Journal of Agronomy and Food Chemistry, 58(16), 9043-9053. http://dx.doi.org/10.1021/jf1008023. PMid:20669951.

Souza, M. F. (2009). Atividade inseticida de extratos obtidos a partir do resíduo líquido de Ágave Sisalana perrine no controle da praga Spodoptera Frugiperda em milho (Dissertação de mestrado). Universidade Estadual de Feira de Santana, Feira de Santana.

Stevenson, F. J. (1994). Humus chemistry: genesis, composition, reactions (2nd ed.). New York: John Willey.

Teixeira, M. A. (2008). Babassu: a new approach for an ancient Brazilian biomass. Biomass and Bioenergy, 32(9), 857-864. http://dx.doi. org/10.1016/j.biombioe.2007.12.016.

Vieira, A. S., Souza, S. N. M., Bariccatti, R. A., Siqueira, J. A. C., \& Nogueira, C. E. M. (2013). Caracterização da casca de arroz para geração de energia. Revista Varia Scientia Agrárias, 3(1), 51-57.

Wild, P., Reith, H., \& Heeres, H. (2011). Biomass pyrolysis for chemicals. Biofuels, 2(2), 185-208. http://dx.doi.org/10.4155/bfs.10.88. 